\title{
Differences in Increasing The Ability of Reasoning in Problem Based Learning Model and Computer-Based Investigation Group
}

\author{
Agus Syafrizal ${ }^{1 *}$, Edi Syahputra ${ }^{2}$ and $\operatorname{Irvan}^{1}$ \\ ${ }^{1}$ Master Program of Mathematics Education, Universitas Muhammadiyah Sumatera Utara, Medan, Indonesia, 20371 \\ ${ }^{2}$ Master Program of Mathematics Education, Postgraduate of Universitas Negeri Medan, Medan, Indonesia, 20221 \\ *Corresponding author: agus09syafrizal@gmail.com | Phone Number: +6282304588541
}

\section{ARTICLE HISTORY}

Received : 22 March 2020

Revised : 18 May 2020

Accepted : 12 September 2020

\section{KEYWORDS}

Group Investigation; Problem Based Learning; Mathematical Reasoning; Ability;

\begin{abstract}
This study was conducted to determine whether there were significant differences between students 'reasoning abilities taught using the PBL model and with the Computer Multimedia Assisted GI, and to determine whether or not there was an influence of interaction between learning models and students' initial abilities on mathematical reasoning abilities. This research is a comparative research with treatment. The population in this study were students of MTs Al-Washliyah 28 Sergai. The variables in this study are mathematical reasoning abilities by collecting data using a questionnaire and tests of mathematical reasoning abilities as well as student achievement tests. The analysis prerequisite test uses the Kolmogorov-Smirnov normality test with a sig (2-tailed) value for the Computer Multimedia Assisted PBL class is $0.200^{*}>0.005$ and the sig (2-tailed) value for the computer multimedia-assisted $\mathrm{Gl}$ class is $0.132>0.005$. Hypothesis testing uses 2 path analysis of variance (Anova) with SPSS aids. The results showed that there were significant differences between students' reasoning abilities taught with the PBL and with the Computer Multimedia Assisted GI with a sig value of $0,000<0.05$. And there is no effect of interaction between learning models and students' initial abilities on students reasoning abilities with a sig value of $0.175>0.05$.
\end{abstract}

\section{INTRODUCTION}

In today's modern age, the rapid change and development of science and technology greatly affects all aspects of one's life and personality. In line with the progress of the science and technology, the education world must be able to improve itself and follow the developments that occur. This requires the teacher's role as teaching staff so that they can adapt to existing patterns, especially in improving the ability of reasoning that exists in students.

According to Burais, Ikhsan, Duskri (2016: 77) explained that mathematics is one of the subjects studied at every level of education to equip students to have the ability to think logically, critically, systematically, analytically, and creatively. Mathematics also has an important role in various other scientific disciplines and has a role to develop the power of human thought. Therefore, students must master mathematics so that it will be easier to understand other fields of science.

In addition, Arrahim and Amalia (2018: 21) also revealed that mathematics is a strategy in assuming and logical thinking processes, symbolic language that can be understood by all civilized nations, the art of music is full of symmetry, patterns, and rhythms that can entertain, tools for party makers of architects, space navigators, machine makers and transporters. Mathematics is realized as a result of human ideas related to ideas, processes, and reasoning. Mathematics is an analysis of patterns and relationships, ways of thinking through organizational strategies, analysis and synthesis, art, language, and tools to solve abstract and practical problems.
Based on observations made by researchers at MTs Al-Washliyah 28 Serdang Bedagai, by interviewing mathematics subject teachers that an important problem in learning mathematics at the school is the low learning outcomes and student achievement due to low student reasoning abilities as well. This can be seen in the average results of tests in the last semester that did not meet the standard value of the Minimum Completeness Criteria applied by the school that is equal to 75 .

Depdiknas (2006: 6) explains that reasoning ability is one of the achievements in learning mathematics in schools such as training in thinking, and reasoning in drawing conclusions, developing the ability to solve problems, and developing the ability to convey information or communicate ideas through oral, written, pictures, graphs, maps, diagrams, and so on.

According to Fahmi, Syahputra, and Rajagukguk (2016: 90) said that mathematical reasoning is one of the skills or abilities that are expected to be owned by students, so that later students can understand, think, prove and evaluate the material provided by the teacher. Reasoning ability is very important in understanding mathematics, exploring, ideas, estimating solutions, and applying mathematical expressions in relevant mathematical contexts, and understanding that mathematics is meaningful.

Patiawati, Sugiatno and Yani (2017: 2) also explained that the ability of reasoning is one of mathematical power (mathematical power) that is a concern in the learning of mathematics today. This is supported because reasoning is a 
logical way of thinking that helps students decide whether and why students' answers are logical. Students need to develop the habit of giving arguments or explanations as an integral part of each solution. Investigating answers is a process that can improve understanding of concepts.

The reality on the ground shows that students' mathematical reasoning abilities are still low, both overall and grouped according to their cognitive stages. The low mathematical reasoning ability of students will have an impact on low learning achievement, this is in accordance with the findings in his research that found that one of the tendencies that caused a number of students to fail to master the subjects in mathematics as a result of students not using reason and logic in solving problems or mathematical problems given (Nurhajati, 2014; Nasir, \& Hadijah, 2019). The low ability of mathematical reasoning is caused by the application of learning models that seem monotonous (conventional) and causes students to feel bored and pay less attention because the learning process takes place in one direction and the teacher as the center or source of learning or in other words during the learning process more active teachers than the students (Baist et al, 2019; Dasining et al, 2019; Royani, \& Agustina, 2019; Erma et al, 2019).

Problem-based learning or Problem-Based Learning was first introduced in the early 1970s as an effort to find solutions in diagnosing diseases by making questions according to the situation. Problem-based learning is learning that begins with the presentation of contextual problems to understand concepts and master all other mathematical abilities, students not only receive information but also contribute to building broad and detailed knowledge (Nurhadi et al, 2019; Putra \& Ikhsan, 2019). Mulyana (2015: 43) suggests ten main characteristics of problem-based learning, as follows: a) the problem becomes a starting point in learning; b) the issues raised are real and unstructured problems; c) the problem requires multiple perspectives (multi perspective); d) the problem is challenging students think; e) learning self-direction becomes the main thing; f) utilizing diverse sources of knowledge and evaluating sources of information are essential processes in PBM; g) learning collaboratively, communicatively and cooperatively; h) the development of inquiry and problem solving skills is as important as mastery of the material; i) openness in synthesizing and integrating; j) PBM involves evaluating and reviewing experiences and learning processes.

In addition, Jurotun (2017: 28) explained that the Problem Based Learning (PBL) model is a learning model that challenges students to "learn how to learn", work in groups to find solutions to real-world problems. The problem given is used to bind students to curiosity in the intended learning. Problems are given to students, before students learn concepts or materials relating to problems that must be solved (Kaharuddin, 2019; Erma et al, 2019; Sahrudin, 2019; Fadilla et al, 2020).

The Group Investigation Model is cooperative learning involving small groups, where students work using planning, projects, group discussions, and presenting their findings to the class. According to Sari, Yerizon and ZA (2012: 41) "cooperative learning emphasizes group goals and success, which can only be achieved if all group members achieve material goals". So in cooperative learning, group success is highly valued, so that the enthusiasm of students will be encouraged so that the group is successful.

The stages of Group Investigation learning are 1) choosing a topic, where students choose specific subtopics in a general problem area that is usually determined by the teacher, 2) cooperative planning, students and teachers plan learning procedures, assignments and special goals consistent with the selected subtopic, 3) implementation, i.e. students apply the plan they have developed, 4) analysis and synthesis, students analyze and synthesize information obtained at the implementation stage, 5) presentation of final results, students present their work, 6) evaluation, students and teachers evaluate each group contribution to class work as a whole.

According to Haryati (2018: 54) said that the Group Investigation model is a learning model that encourages students to gather information to solve problems and activate the ability to think higher. In other words, that this learning model can provide a learning environment conducive to the occurrence of more effective teaching and learning interactions, so students can build their own knowledge. Istiqlal (2010: 44) said in his journal that the use of mathematics learning tools with learning media is everything that is able to convey or distribute information effectively and efficiently in learning activities. In addition, learning media have the ability to provide the same stimulation, equalize experience, and give rise to the same perception. The selection of appropriate learning media can be influential in realizing the achievement of learning objectives. Computer-aided multimedia learning is expected to attract students 'enthusiasm in learning so that students' mathematical reasoning abilities will increase. Because with the help of computer multimedia, students are more directed in learning mathematics, so the learning process will be more effective.

The use of learning devices assisted by technology was significantly very effective in improving student learning outcomes in mathematics (Erly, 2013; Muliyono et al, 2019). The effectiveness in using computer multimedia can not be separated from the direction and guidance of the teacher so that the concepts needed do not violate the terms of problem-solving provided and the material taught is more quickly understood by students. Related to the problem above, the researcher wants to see whether there is a difference in students' mathematical reasoning abilities taught by Problem Based Learning and with students taught with Group Investigation assisted with computer multimedia models. Researchers are eager to try to do research related to students' mathematical reasoning ability at MTs Al-Washliyah 28 Serdang Bedagai and are given the title "Differences in Increasing Reasoning Ability in Problem Based Learning Models and Investigation Groups Assisted by Computer Multimedia".

\section{RESEARCH METHOD}

The method or design used in this study is quasi-experimental (Quasi Experiment Design). The subjects of this study were students of class VII-A and class VII-B MTs Al-Washliyah 28 Serdang Bedagai and wanted to see how differences in students' reasoning abilities increase in mathematics learning on the Factor Material of Algebra Tribe.

While the research design was carried out using a pretest-posttest control group design with two types of treatment. In this study, using two sample classes that were given different treatments. Before receiving treatment, students are given a pre-test (pretest) to determine the students' initial abilities. In experimental class I, students will be taught a lesson using a computer-aided multimedia Problem Based Learning (PBL) model and in experimental class II students will be taught a lesson using a computer multimedia-assisted Group Investigation (GI) model. 
Table 1. Research Design

\begin{tabular}{cccc}
\hline Sample Group & Pre-Test & Treatment & Post-Test \\
\hline Experiment I & $\mathrm{T}_{1}$ & $\mathrm{X}_{1}$ & $\mathrm{~T}_{2}$ \\
Experiment II & $\mathrm{T}_{1}$ & $\mathrm{X}_{2}$ & $\mathrm{~T}_{2}$ \\
\hline
\end{tabular}

\section{Information :}

$\mathrm{T}_{1}$ : $\quad$ Giving the pretest

\section{$\mathrm{T}_{2}$ : $\quad$ Giving the posttest}

$\mathrm{X}_{1}$ : $\quad$ The treatment given to the experimental class I by using a computer-aided multimedia-based Problem Based Learning model

$\mathrm{X}_{2}$ : $\quad$ The treatment given to the experimental class I by using a computer-aided multimedia-based Group Investigation model

The instruments used in collecting data are the mathematical reasoning test and learning achievement test instruments. Research instruments have been prepared and tested for validity, reliability, level of difficulty and distinguishing power before use using SPSS 25 for Windows software. This test is carried out to determine the appropriateness of the instruments to be used in research.

All statistical calculations carried out in this study use the help of the SPSS 25 software program for windows. The statistical model of this Experiment Research (Syahputra, 2016: 169), namely:

$$
Y_{i j k}=\mu+\alpha_{i}+\beta_{j}+(\alpha \beta)_{i j}+\varepsilon_{i j k}
$$

With : $i=1,2 ; \quad j=1,2 ; \quad k=1,2, \ldots, 30$

Information:

$Y_{i j k}=$ Score of student's reasoning ability on the " $k$ ", learning on the " $j$ " and the first mathematical ability on the " $i$ ".

$\mu \quad=$ Average score of actual ability

$\alpha_{i} \quad=$ Effect of additives from early mathematical abilities on the " $i$ "

$\beta_{j} \quad=$ Effect of additives from models on the " $j$ ".

$(\alpha \beta)_{i j}=$ Influence of interactions from initial mathematical abilities to " $i$ " and models to " $j$ ".

$\varepsilon_{i j k}=$ Effect of experimental deviation from student scores to

" $k$ ", in the early abilities of mathematics to " $i$ ", which gets the learning to " $j$ ".

Then the statistical hypothesis that will be used is as follows :

$$
\begin{aligned}
& \mathrm{H}_{0}: \beta_{11}=\beta_{12}=0 \\
& \mathrm{H}_{a}: \beta_{11} \neq \beta_{12} \\
& \mathrm{H}_{0}: \beta_{21}=\beta_{22}=0 \\
& \mathrm{H}_{a}: \beta_{21} \neq \beta_{22} \\
& \mathrm{H}_{0}:(a \beta)_{i j}=0 \\
& \mathrm{H}_{a}: \text { ada satu pasang }(a \beta)_{i j} \neq 0 \\
& \mathrm{H}_{0}:(a \beta)_{i j}=0 \\
& \mathrm{H}_{a}: \text { ada satu pasang }(a \beta)_{i j} \neq 0
\end{aligned}
$$

\section{RESULTS AND DISCUSSION}

This research was carried out from 2 to 28 February 2019 at MTs Al-Washliyah 28 Serdang Bedagai. The population in this study were all students of class VII which consisted of three classes, namely class VII-A, VII-B, and VII-C totaling 90 students and the samples in this study were class VII-A and class VII-B amounting to 30 students each. Computer multimedia-assisted Problem Based Learning models are used in experimental class I and computer multimedia-assisted

\begin{tabular}{|c|c|c|c|c|c|c|c|c|c|}
\hline \multirow[t]{3}{*}{ Qualification } & \multirow[t]{3}{*}{ Score } & \multicolumn{4}{|c|}{$\begin{array}{c}\text { Computer Multimedia } \\
\text { Assisted Problem Based } \\
\text { Learning } \\
\end{array}$} & \multicolumn{4}{|c|}{$\begin{array}{c}\text { Computer } \\
\text { Multimedia Assisted } \\
\text { Group Investigation } \\
\end{array}$} \\
\hline & & \multicolumn{2}{|c|}{ Pretest } & \multicolumn{2}{|c|}{ Posttest } & \multicolumn{2}{|c|}{ Pretest } & \multicolumn{2}{|c|}{ Posttest } \\
\hline & & $\mathrm{F}$ & $(\%)$ & & $(\%)$ & & $(\%)$ & & $(\%)$ \\
\hline Very Good & $91-100$ & 0 & 0,00 & & 23,3 & & 0,00 & & 0,00 \\
\hline Good & $75-90$ & 0 & 0,00 & 3 & 76,7 & & 0,00 & 7 & 56,67 \\
\hline Enough & $60-74$ & 0 & 0,00 & & 0,00 & & 0,00 & 3 & 43,33 \\
\hline Less & $40-59$ & 2 & 73,3 & & 0,00 & & 20,0 & & 0,00 \\
\hline Very Less & $<40$ & 8 & 26,7 & & 0,00 & 4 & 80,0 & & 0,00 \\
\hline Amount & & 0 & 100 & 0 & 100 & 0 & 100 & 0 & 100 \\
\hline
\end{tabular}
Group Investigation models are used in experiment class II. The purpose of the results is to see the extent of differences in students' mathematical reasoning abilities in mathematics by applying the Problem Based Learning and Group Investigation models assisted with computer multimedia.

Table 2. The Initial and Final Ability Data In Problem Based Learning Class and Computer Multimedia-Assisted Group Investigation Class

Sources for data processing in 2019

In Table 2 pre-test results obtained in both classes are included in the qualification less (with a range of grades 40-59) and very poor qualifications (with a range of values $<40$ ). Thus it can be concluded that the experimental class I and experimental class II have relatively similar initial abilities.

Table 3. Average Data and Standard Deviations of Students Mathematical Reasoning Abilities

\begin{tabular}{lcccc}
\hline \multicolumn{1}{c}{ Class } & Type of Test & $\mathrm{N}$ & Mean & Std. Deviation \\
\hline Computer Multimedia Assisted & Pretest & 30 & 43,13 & 7,14738 \\
\cline { 2 - 5 } Problem Based Learning & Posttest & 30 & 85,93 & 5,03048 \\
\hline Computer Multimedia Assisted & Pretest & 30 & 35,67 & 4,73675 \\
\cline { 2 - 5 } Group Investigation & Posttest & 30 & 75,73 & 4,63817 \\
\hline
\end{tabular}

Sources for data processing in 2019.

In Table 3 The average value of pretest and posttest obtained from Problem Based Learning with computer multimedia assisted and Computer Investigation assisted with computer multimedia classes, can be concluded as follows:

Mathematical reasoning ability of students who use the multimedia multimedia-based Problem Based Learning learning model has a significant increase in average value. The point of pretest is 43.13 and 85.93 posttest, so that from the average value of pretest and posttest there was an increase of 42.8 .

Mathematical reasoning ability of students who use Group Investigation learning models assisted with computer multimedia has increased the average value which is not so great. pretest value of 35.67 and 75.73 posttest, so that from the average value of pretest and posttest there is an increase of 40.06 .

Because the data that has been previously processed shows homogeneous results, we refer to the output results of Equal variances assumed. Based on the output in Table 1.11. explained that the value of Sig. (2-tailed) of $0,000<0.05$, it can be concluded that there is an average difference in the results of the posttest of students' mathematical reasoning ability between the experimental class I using a computer-aided multimedia-based PBL and the experimental class II using the Group Investigation model Computer-aided multimedia. 
Table 4. N-Gain Normality Test Results Score Students' Mathematical Reasoning Ability

\begin{tabular}{|c|c|c|c|c|}
\hline \multirow{2}{*}{ Class } & \multicolumn{3}{|c|}{ Kolmogorov-Smirnova } & \multirow{2}{*}{ Conclusion } \\
\hline & Statistic & Df & Sig. & \\
\hline $\begin{array}{l}\text { Posttest Computer } \\
\text { Multimedia Assisted } \\
\text { Problem Based Learning }\end{array}$ &, 117 & 30 & ,200* & $\begin{array}{l}\text { Data is normally } \\
\text { distributed }\end{array}$ \\
\hline $\begin{array}{l}\text { Posttest Computer } \\
\text { Multimedia Assisted } \\
\text { Group Investigation }\end{array}$ &, 141 & 30 &, 132 & $\begin{array}{l}\text { Data is normally } \\
\text { distributed }\end{array}$ \\
\hline Sources for data process & $\operatorname{g}$ in 2019 & & & \\
\hline
\end{tabular}

From Table 4. it was found that the n-gain score of the reasoning ability of students using Computer Multimedia Assisted Problem Based Learning had a Sig value of 0.200 * and the Group Investigation class assisted with computer multimedia had a Sig value of 0.132 . Based on these values it can be reported that the two data are normally distributed in accordance with the predetermined variance normality requirements.

Table 5. Homogeneity Test Results of Students' Mathematical Reasoning Abilities

\begin{tabular}{llcccc}
\hline & & $\begin{array}{c}\text { Levene } \\
\text { Statistic }\end{array}$ & df1 & df2 & Sig. \\
\hline The_result_of_rea Mean & 2,329 & 3 & 116 &, 078 \\
\cline { 2 - 6 } \begin{tabular}{l} 
soning_ability \\
\cline { 2 - 6 }
\end{tabular} & $\begin{array}{l}\text { Median } \\
\text { Median and with } \\
\text { adjusted df }\end{array}$ & 1,873 & 3 & 92,582 &, 140 \\
\cline { 2 - 6 } & $\begin{array}{l}\text { Based on } \\
\text { trimmed mean }\end{array}$ & 2,315 & 3 & 116 &, 079 \\
\hline
\end{tabular}

Tests the null hypothesis dependent variable is equalacross groups.

a. Dependent variable: Hasil_Kemampuan_Penalaran

b.Design: Intercept + Model_Pembelajaran + Test + Model_Pembelajaran * Test

Sources for data processing in 2019.

Based on Table 5. can be seen in the results of data processing output, on the line based on mean that the homogeneity of the two variances has a significant value of 0.078 , so it can be concluded that both data are homogeneous in variance.

Because the data meets the requirements for normality and homogeneity, the average similarity test to be used is the two-way ANOVA test as shown in Table 6.

Table 6. Between Subjects Factors

\begin{tabular}{cclcc}
\hline & \multicolumn{3}{c}{ Value Label } & N \\
\hline \multirow{2}{*}{ Learning_model } & 1 & $\begin{array}{l}\text { Computer } \\
\text { Problem Based Learning }\end{array}$ & Multimedia Assisted & 60 \\
\cline { 2 - 4 } Test & 2 & $\begin{array}{l}\text { Computer Multimedia Assisted Group } \\
\text { Investigation }\end{array}$ & 60 \\
\hline & 1 & Pretest & 60 \\
\cline { 2 - 4 } & 2 & Posttest & 60 \\
\hline
\end{tabular}

Sources for data processing in 2019.

Table 7. The Results Levene's Test of Equality of Error Variances ${ }^{\mathrm{a}, \mathrm{b}}$

\begin{tabular}{cccl}
\hline Levene Statistic & df1 & df2 & Sig. \\
\hline 2,329 & 3 & 116 &, 078 \\
\hline
\end{tabular}

Tests the null hypothesis that the error variance of the dependent variable is equal across groups.

a. Design: Intercept + Learning_model + Test + Learning_model * Test

Sources for data processing in 2019
At the output of Table 7 . the results of table above obtained Sig value of 0.078 . Since the Sig value of $0.078>0.05$, it can be concluded that the variant of the outcome variable of students' mathematical reasoning abilities is homogeneous, so the assumption of homogeneity in the two-way ANOVA test is fulfilled.

After the data has been tested for normality and homogeneity, then the use of two average similarity tests can be continued with hypothesis testing. The ANOVA test is then used to see whether there is a significant difference between the reasoning abilities of students taught in experimental class I (with a computer-aided multimedia-based Problem Based Learning model) and students taught in experimental class II (with a computer multimedia-assisted Group Investigation model). Testing the statistical hypothesis in this study using the two-way ANOVA formula, the results are in Table 8. the following.

Table 8. The ResultsTest of Between-Subjects Effects Dependent Variable: The_result_of_reasoning_ability

\begin{tabular}{|c|c|c|c|c|c|}
\hline Source & $\begin{array}{c}\text { Type III Sum } \\
\text { of Squares }\end{array}$ & Df & Mean Square & $\mathbf{F}$ & Sig. \\
\hline Corrected & $53898,500^{a}$ & 3 & 17966,167 & 597,179 & ,000 \\
\hline \multicolumn{6}{|l|}{ Model } \\
\hline Intercept & 433681,633 & 1 & 433681,633 & 14415,184 &, 000 \\
\hline KAM & 51501,633 & 1 & 51501,633 & 1711,868 &, 000 \\
\hline MODEL & 2340,833 & 1 & 2340,833 & 77,807 & ,000 \\
\hline KAM & 56,033 & 1 & 56,033 & 1,862 &, 175 \\
\hline \multicolumn{6}{|l|}{ MODEL } \\
\hline Error & 3489,867 & 116 & 30,085 & & \\
\hline Total & 491070,000 & 120 & & & \\
\hline Corrected & 57388,367 & 119 & & & \\
\hline Total & & & & & \\
\hline
\end{tabular}

a. R Squared $=, 939$ (Adjusted R Squared $=$,938)

Sources for data processing in 2019

Based of Table 8 . conclusions can be drawn in accordance with the formulation of the problems examined in this study are:

Obtained Sig. of $0,000<0.05$, so it can be concluded that there are differences in the results of students' mathematical reasoning abilities based on the learning model used.

Obtained Sig. of $0,000<0.05$, so it can be underlined that there are differences in the results of students' mathematical reasoning abilities based on the tests given.

Obtained Sig. of $0.175>0.05$, it can be concluded that there is no interaction between the learning model and the test in determining the results of students' mathematical reasoning abilities.

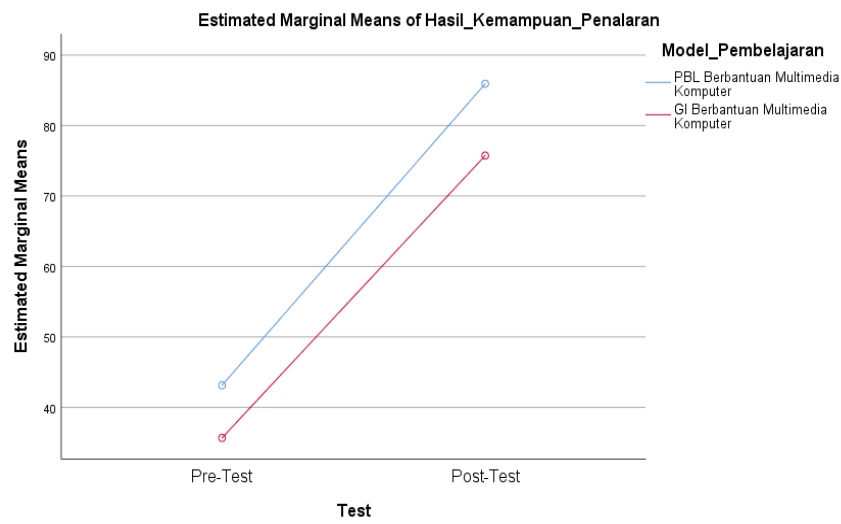

Figure 1. The Estimated Marginal Means Graphic Results From Reasoning Ability 


\section{CONCLUSION}

Based on the results described in the previous chapters, with reference to the hypothesis formulated with a confidence level of $95 \%(a=0.05)$, the following conclusions are obtained:

a. There is a significant difference between the mathematical reasoning students with the computer multimedia-assisted PBL model and with students who get learning with the Computer Multimedia-assisted Group Investigation model.

b. The influence of the interaction between the learning model and students' initial abilities on students reasoning abilities.

Based on the above research conclusions, then there are some things that the authors suggest include:

a. The Problem Based Learning model assisted by computer multimedia should be able to be an alternative learning as an implementation of the development of mathematics learning, especially in improving students' mathematical reasoning abilities.

b. Problem-based learning models assisted with computer multimedia can be further investigated to improve other mathematical abilities such as mathematical understanding abilities, mathematical problem solving abilities, mathematical connection abilities, mathematical critical thinking abilities, mathematical creative thinking and mathematical communication skills.

c. Problem Based Learning models assisted by computer multimedia that are well managed in the learning process can provide a conducive learning atmosphere. The results of this study should be used as a reference for teachers to guide students to optimize mathematical reasoning abilities and apply learning in a variety of other mathematical subjects.

\section{REFERENCES}

Arrahim dan Amalia, Serly. (2018). Penerapan Model Pembelajaran Kooperatif Tipe Team Assisted Individualization (TAI) untuk Meningkatkan Kemampuan Pemecahan Masalah pada Mata Pelajaran Matematika Kelas IV SD Negeri Wanasari 14 Cibitung - Bekasi. Jurnal Pedagogik Volume VI Nomor 1, Februari 2018 : 21-30

Baist, A., Fadillah, A., \& Nopitasari, D. (2019). Students Self Regulated Learning in Numerical Methods Course using Computational Mathematics Teaching Materials. Malikussaleh Journal of Mathematics Learning (MJML), 2(1), 1-4.

Burais, Listika, Ikhsan, M dan Duskri, M. (2016). Peningkatan Kemampuan Penalaran Matematis Siswa melalui Model Discovery Learning. Jurnal Didaktik Matematika Volume 3 Nomor 1, April 2016 : 77-86.

Depdiknas. (2006). Permendiknas No.22 Tahun 2006 Tentang Standar Isi. Jakarta : Depdiknas.

Dasining, D., Muslim, S., \& Handajani, S. (2019). The Effect of Problem Based Learning Models and Levels of Creativity Toward Student Outcomes in Vocational High School. International Journal for Educational and Vocational Studies, 1(6), 595-598.

Erly, S. (2013). Pengembangan Bahan Ajar Matematika Berbasis ICT pada Model Pembelajaran JIGSAW Materi Differensial. Artikel Penelitian Fakultas MIPA : IKIP Semarang.

Erma, E., Koeswanti, H. D., \& Giarti, S. (2019). Improving Critical Thinking Skills Using Problem Based Learning on the Media Flash Card. International Journal for Educational and Vocational Studies, 1(6), 619-622.

Fadilla, N., Nurlaela, L., \& Maspiah, M. (2020). Application of Problem Based Learning Method in Entrepreneurship and Hygiene Sanitation with Flipped Classroom Strategy. International Journal for Educational and Vocational Studies, 1(8).

Fahmi, Akmal, Syahputra, Edi dan Rajagukguk, W.R.. (2016). Peningkatan Kemampuan Penalaran dan Komunikasi Matematik Siswa Melalui Model Pembelajaran Berbasis Masalah Berbantuan Geo-Gebra di Kelas VIII SMP Negeri 1 Samudera. Jurnal Paradikma Volume 9 No.1 April 2016 : 88-100

Haryati, Yayah. (2018). Penerapan Model Pembelajaran Kooperatif Tipe Group Investigasi Untuk Meningkatkan Aktivitas dan Hasil Belajar Matematika. Jurnal Penelitian Pendidikan ISSN 1412-565 X : 53-64

Istiqlal, Muhammad. (2010). Pengembangan Multimedia Interaktif Dalam Pembelajaran Matematika. Jurnal Ilmiah Pendidikan Matematika Volume 2 Nomor 1 : 43-54.

Jurotun. (2017). Meningkatkan Aktivitas dan Hasil Belajar Siswa melalui Model PBL-STAD berbantuan Geogebra Materi Program Linier Kelas XI MIPA. Jurnal KREANO Volume 8 Nomor 1 June 2017 : 35-46.

Kaharuddin, A. (2019). Effect of Problem Based Learning Model on Mathematical Learning Outcomes of 6th Grade Students of Elementary School Accredited B in Kendari City. International Journal of Trends in Mathematics Education Research, 1(2).

Mulyana, Ade. (2015). Meningkatkan Kemampuan Penalaran Matematik dan Kemandirian Belajar Siswa SMP Melalui Pembelajaran Berbasis Masalah. Jurnal Ilmiah STKIP Siliwangi Bandung Volume 9 Nomor 1, Maret 2015 : 51.

Muliyono, M. R., Suyanto, T., \& Yani, M. T. (2019). The Effect of Problem Based Learning Model on Understanding Concepts and Problem Solving Skill in Social Sciences in Grade IV Students of SDN 1 Mulung Driyorejo Gresik. International Journal for Educational and Vocational Studies, 1(3), 229-235

Nasir, A. M., \& Hadijah, H. (2019). The Effectiveness of Problem Based Learning Model With The Assistance of Animation Media on Tetragon Material To The Students Mathematic Learning Achievement of Grade Vii Smp Negeri 5 Mandai. Malikussaleh Journal of Mathematics Learning (MJML), 2(1), 13-18.

Nurhajati. (2014). Pengaruh Penerapan Pendekatan Konstruktivisme dengan Model Pembelajaran Kooperatif Berbantuan Program Cabri 3D Terhadap Kemampuan Penalaran dan Koneksi Matematis Siswa SMA di Kota Tasikmalaya. Jurnal Pendidikan dan Keguruan Volume 1 Nomor 1, $2014: 1-11$.

Nurhadi, M., Hizqiyah, I. Y. N., \& Saraswati, A. (2019). Application of The Problem Based Learning Method Trought Authentic Assessment Approach to Improving the Habits of Mind. International Journal of Trends in Mathematics Education Research, 2(2), 68-71.

Patiawati, Yasmin, Sugiatno dan Yani, Ahmad. (2017). Penerapan Model Problem Based Learning dengan Pendekatan Saintifik untuk Meningkatkan Kemampuan Penalaran Adaftif Siswa SMP. Artikel Penelitian Prodi Pendidikan Matematika FKIP Universitas Tanjungpura : $1-15$.

Putra, P., \& Ikhsan, M. (2019). Mathematical Reasoning Ability and Learning Independence of High School 
Students Through Problem Based Learning Model. International Journal for Educational and Vocational Studies, 1(3), 217-223.

Royani, M., \& Agustina, W. (2019). Junior High School Students Ability to Use The Polya's Step to Solve Mathematical Problems Through Problem Based Learning. International Journal of Trends in Mathematics Education Research, 2(2), 86-90.

Sahrudin, A. (2019). Development of Problem Based Learning Method To Increase Students' Mathematical Problem Solving Ability at Numbers Theory Courses. International Journal of Trends in Mathematics Education Research, 2(2), 96-100.

Sari, Devi Permata, Yerizon, dan ZA, Nilawati. (2012). Dampak Pembelajaran Kelompok Investigasi dalam Belajar Matematika Terhadap Kemampuan Penalaran. Jurnal Pendidikan Matematika Volume 1 Nomor 1 : 40-45.

Syahputra, Edi (2016) Statistika Terapan Untuk Quasi dan Pure Experiment di Bidang Pendidikan, Biologi, Pertanian, Teknik, dll. Medan : Unimed Press. 